\title{
Exposition of cork oak roots to cryptogein reduced the infection by Phytophtora cinnamomi
}

\author{
I.Maia*, C. Medeira*, I.Diniz*, I.Candeias,* E.Melo*, A.Cravador** \\ *INRB/L-INIA/URGEMP. Av. da República, Quinta do Marquês. 2784-505 Oeiras, Portugal \\ ${ }^{* *}$ Universidade do Algarve, FERN, Campus de Gambelas, 8005-139 Faro, Portugal and IBB/CGB- \\ UTAD Apartado 10103, 5001 Vila Real, Portugal \\ isabel.maia@netcabo.pt
}

The oomycete $P$. cinnamomi has been described as strong contributing factor to the decline of cork oak and holm oak stands occurring in the Iberian Peninsula. There are no eradication methods available against this pathogen.

Molecular mechanisms of oomycete - host interaction are not well understood, but it is known that oomycete species can induce biochemical and physiological processes in their host plants through a diverse array of virulence or avirulence molecules, known as effectors. Several Phytophtora effector molecules, the elicitins, are able to induce cellular defence responses in plants. Among these elicitors the 10- KDa (elicitins) are able to enhance plant defences in a systemic acquired resistance manner, against infection of different pathogens $[1,2,5]$.

In the present study we analysed the effects of the elicitin cryptogein, secreted by P. cryptogea, in the $P$. cinnamomi infection process of cork oak plantlets obtained in vitro.

The in vitro shoots were raised on GD medium plus BA+IAA, rooted on the same medium without hormones, after a $2 \mathrm{~min}$ dip in an IBA solution, transferred to liquid medium for root development and plantlets placed on a thin layer of solid medium in Petri dishes. Two $5 \mu \mathrm{l}$ drops of a $[5 \mu \mathrm{g} / \mathrm{ml}]$ cryptogein water solution were placed on each treated root at about $5 \mathrm{~mm}$ from the cap. The roots were inoculated $24 \mathrm{~h}$ later by introducing a plug of actively growing mycelium of $P$. cinnamomi isolate $X X-1 B$, lasting for 2 days (Fig. 1 ).

For microscopic observations root fragments were collected from the inoculated zone and processed according Medeira et al., 2006. For each treatment four plants were used and two roots from each one were collected. Five hundred sections per treatment were observed by light microscopy and one hundred selected sections were examined under transmission electron microscopy.

Phytophtora cinnamomi invaded the cortex (Fig.2A) and the vascular cylinder (Fig.2B) in all the non-treated root sections. The pathogen showed a vigorous and active aspect (Fig.3). In cryptogein treated roots the pathogen migration was strongly reduced. The vascular cylinder colonization did not occurred in $94 \%$ of observed sections. The ultrastructural observation of cryptogein pre-treated and inoculated roots, revealed a gradient of disorganization of $P$. cinnamomi in the cortical parenchyma cells. Membrane degradation, loss of organelle integrity and cytoplasm agglutination is the main feature evidencing the pathogen unavailability (Figs.4A and 4B). The appearance of fibrillar and granular electron-opaque materials in the intercellular spaces of the cortical parenchyma around the disorganized hyphae (Figs. 4A to 4E) and the deposition of electron-dense layers bordering the vacuoles of cortical parenchyma cells (Fig.4E) suggest a defence response of the cryptogein pre-treated roots against the pathogen.

Similar cytological alterations were considered as host resistance induced by other elicitins such as oligandrin on tomato plants against $P$. parasitica [5] or on tobacco plants treated with cryptogein against the same pathogen [2]. These authors support that electron-dense materials found around the hyphae were phenolic compounds accumulated as defence response. The accumulation of electron- 
dense deposits along the tonoplast of cortical cells in cork oak treated roots was also referred as a defence reaction described in grapevine treated with oligandrin against Botrytis cinerea [4]. Cryptogein absorbed by plantlet roots of cork oak induced resistance responses to $P$. cinnamomin, strongly reducing its invasion into vascular cylinder.

\section{References}

[1] N. Benhamou, R. Bélanger, P. Rey, Y. Tirilly. Plant Physiol Biochem 39 (2001): 681.

[2] J. Lheirminier, N. Benhamou, J. Larrue, M-L Milat, E. Boudon-Padieu, M. Nicole, J-P Blein. Phytopathology, 93 (2003): 1308.

[3] Medeira, M.C., Maia, M.I., Carvalho, M.T. J Horticult Sci and Biotech 81 (2006): 251.

[4] N. Mohamed, J. Lheirminier, M-J. Farmer, J. Fromentin, N. Béno, V. Houot, M-L Milat, J-P Blein. Phytopathology 97 (2007): 611.

[5] K. Piccard, M. Ponchet, J-P. Blein, P. Rey, Y. Tirilly, N. Benhamou. Plant Physiology 124 (2000): 379.
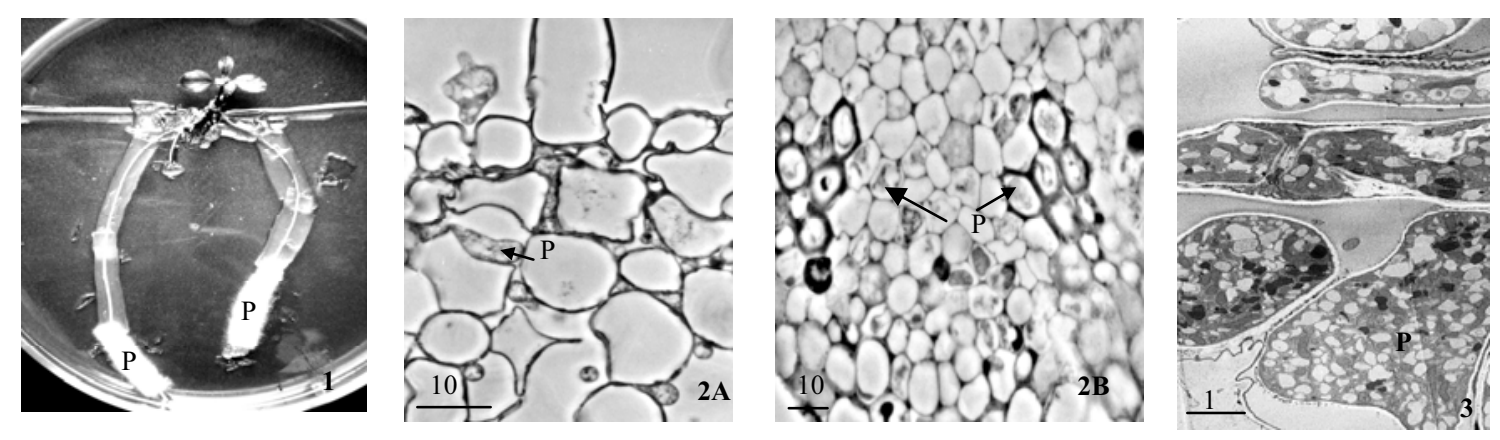

Fig.1. Cork oak plantlet with the inoculum $(\mathrm{P})$ on the roots.

Fig.2. Phytophtora cinnamomi (P) invaded all tissues of the root; the cortex (2A) and the vascular cylinder (2B).

Fig.3. The pathogen $(\mathrm{P})$ showed vigorous and active aspect in non treated roots.
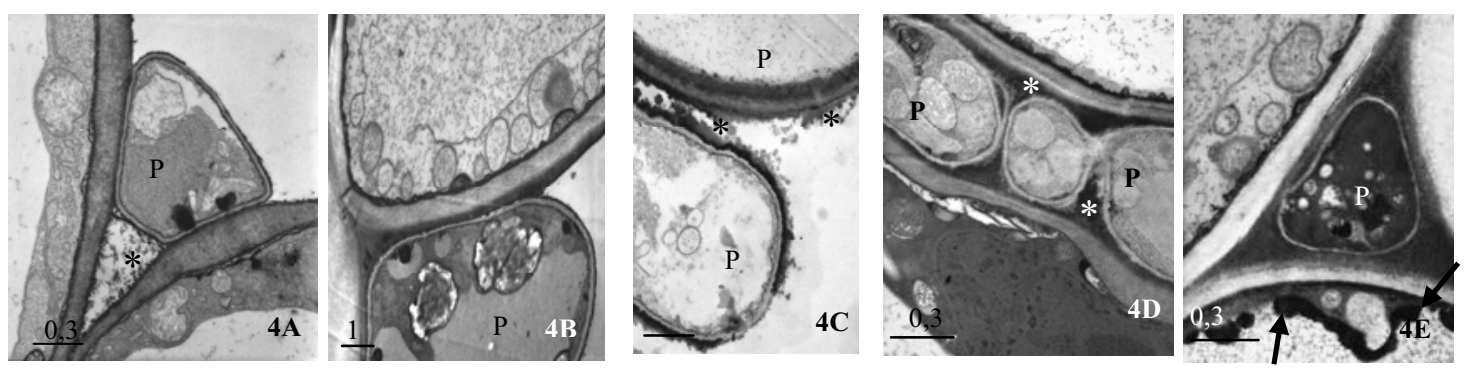

Fig 4A to E. Cryptogein pre-treated and inoculated roots, revealed a gradient of disorganization of $P$ cinnamoni in the cortex.

Figs. 4C to 4E. Fibrillar and granular electron-opaque materials $\left(^{*}\right)$ in the intercellular spaces around hyphae $(* *)$. Fig.4E. Electron-dense layers bordering the vacuoles (arrows).

This work was supported by PTDC-AGR-AAM 67628 project

The cryptogein was provided by M. Ponchet, INRA, France. 